\title{
OPTIMALISASI KEBUTUHAN GIZI PADA MENU MAKANAN IBU HAMIL ANEMIA MENGGUNAKAN METODE BRACH AND BOUND \\ (Studi Kasus di Kecamatan Ampana Tete Kabupaten Tojo Una-Una Provinsi Sulawesi Tengah)
}

\author{
Zulhajrah $^{1}$, A. I. Jaya², dan A. Sahari ${ }^{3}$ \\ 123Program Studi Matematika Jurusan Matematika FMIPA Universitas Tadulako \\ Jalan Soekarno-Hatta Km. 09 Tondo, Palu 94118, Indonesia \\ 1Zulhajra29@gmail.com, 2jayaindraagus@gmail.com,3agus_sh@yahoo.com
}

\begin{abstract}
Anemia in pregnancy is a common problem because it reflects the value of socio-economic welfare of society and has had enormous influence on the quality of human resources. Settings menu maternal anemia is an effort to maintain the condition of pregnant women with anemia. This study aims to obtain optimal value nutritional needs of pregnant women anemia in Ampana Tete District of Tojo Una-Una Central Sulawesi province by using the branch and bound method. The parameters used in this study are the type of staple foods $\left(x_{1}\right)$, the type of vegetable $\left(x_{2}\right)$, types of fruit $\left(x_{3}\right)$, types of side dishes $\left(x_{4}\right)$, green beans $\left(x_{5}\right)$, and milk $\left(x_{6}\right)$, $\operatorname{Results}$ show 1 st, 2 nd, and 3 rd of 36 combinations known to the most optimal combination for all trimester is a combination of 14 . For the first trimester are as many as rice, $348 \mathrm{~g}$ spinach were $116 \mathrm{~g}$,chicken eggs as 482 gmuch,and green beans $138 \mathrm{~g}$, at a cost of $R p .15680,00,2 \mathrm{nd}$ trimester is as much as rice, $381 \mathrm{~g}$ spinach amount to $167 \mathrm{~g}$, chicken $690 \mathrm{~g}$ eggs, and green beans as much as $154 \mathrm{~g}$ and of milk $3 \mathrm{~g}$ at a cost of $R p 20498,50$, and the third trimester is rice, $345 \mathrm{~g}$ spinach, $127 \mathrm{~g}$, chicken $914 \mathrm{~g}$ eggs, and green beans $176 \mathrm{~g}$, at a cost of $R p .24086 .00$ per day. The analysis has not been as expected because one of the drawbacks is the use of linear programming linearity as sumption that sometimes does not correspond to reality.
\end{abstract}

Keywords : : Anemia, Branch and Bound, Nutrition, Pregnancy.

\section{ABSTRAK}

Anemia pada kehamilan merupakan masalah yang umum karena mencerminkan nilai kesejahteraan sosial ekonomi masyarakat dan pengaruhnya sangat besar terhadap kualitas sumber daya manusia. Pengaturan menu makanan ibu hamil anemia merupakan salah satu usaha untuk menjaga kondisi ibu hamil anemia. Penelitian ini bertujuan untuk memperoleh nilai optimal kebutuhan gizi ibu hamil anemia di Kecamatan Ampana Tete Kabupaten Tojo Una-Una Provinsi Sulawesi Tengah dengan menggunakan Metode branch and bound. Peubah yang digunakan dalam penelitian ini yaitu jenis makanan pokok $\left(x_{1}\right)$, jenis sayur $\left(x_{2}\right)$, jenis buah $\left(x_{3}\right)$, jenis lauk pauk $\left(x_{4}\right)$, kacang hijau $\left(x_{5}\right)$, dan Susu $\left(x_{6}\right)$. Hasil penelitian menunjukkan trimester 1 , 2, dan 3 dari 36 kombinasi diketahui kombinasi yang paling optimal untuk semua trimester adalah kombinasi 14 . Untuk trimester 1 adalah beras sebanyak $348 \mathrm{~g}$, bayam sebanyak $116 \mathrm{~g}$, telur ayam sebanyak $482 \mathrm{~g}$, dan kacang hijau sebanyak $138 \mathrm{~g}$, dengan biaya Rp 15.680,00 , trimester 2 adalah beras sebanyak $381 \mathrm{~g}$, bayam sebanyak $167 \mathrm{~g}$, telur ayam 
sebanyak 690 g, dan kacang hijau sebanyak $154 \mathrm{~g}$, dan susu $3 \mathrm{~g}$ dengan biaya Rp 20.498,50, dan trimester 3 adalah beras sebanyak $345 \mathrm{~g}$, bayam sebanyak $127 \mathrm{~g}$, telur ayam sebanyak $914 \mathrm{~g}$, dan kacang hijau sebanyak $176 \mathrm{~g}$, dengan biaya Rp 24.086,00 per hari. Analisis belum sesuai dengan yang diharapkan karena salah satu kelemahan program linear yaitu penggunaan asumsi linearitas yang terkadang tidak sesuai dengan kenyataan.

Kata kunci : : Anemia, Branch and Bound, Gizi, Ibu Hamil.

\section{PENDAHULUAN}

\subsection{Latar Belakang}

Masalah - masalah kesehatan yang dihadapi bangsa Indonesia sekarang ini adalah masih tingginya angka kematian ibu dan bayi, masalah gizi dan pangan. Masalah tersebut merupakan masalah yang mendasar karena secara langsung menentukan kualitas sumber daya manusia serta meningkatkan derajat kesehatan. Masalah gizi di Indonesia yang belum teratasi, salah satunya adalah anemia (Tarwoto dan Wasnidar, 2007).

Kurangnya pemahaman ibu hamil memilih makanan pada masa kehamilan merupakan salah satu faktor terjadinya anemia. Dalam studi kasus ini diambil permasalahan yang terjadi di wilayah kerja puskesmas Tete kecamatan Ampana Tete Kabupaten Tojo Una-una, tentang pengaturan menu makanan yang mengharuskan terpenuhinya kandungan gizi tertentu untuk ibu hamil anemia dengan biaya minimum. Permasalah penentuan menu makanan bagi ibu hamil anemia trimester 1, 2, dan 3 dengan biaya minimum dapat diselesaikan dengan menggunakan model program linear.

Menurut Hamdy (1996) Program linear sebagai salah satu teknik analisa data kuantitatif, merupakan model matematika yang dapat diterapkan dalam pengambilan keputusan yang telah ditentukan. Banyak persoalan menggunakan program linear, diantaranya persoalan transportasi, program dinamis serta program bilangan bulat (program Integer).

Program linear bilangan bulat dapat diselesaikan dengan banyak cara, antara lain dengan menggunakan grafik, dengan metode eliminasi dan substitusi, dan sebagainya. Salah satu cara yang cukup efektif untuk menyelesaikan masalah program-program linear bilangan bulat adalah dengan mengaplikasikan algoritma Branch and Bound.

Berdasarkan latar belakang tersebut penulis mencoba menuangkan masalah ini ke dalam sebuah tugas akhir yang berjudul “Optimalisasi Kebutuhan Gizi Pada Menu Makanan Ibu Hamil Anemia Menggunakan Metode Branch and Bound“(Studi Kasus di Kecamatan Ampana Tete Kabupaten Tojo Una-una Provinsi Sulawesi Tengah)".

\subsection{Rumusan Masalah}

Berdasarkan latar belakang masalah di atas, maka permasalahan yang diangkat dari penelitian ini adalah bagaimana optimalisasi kebutuhan gizi bagi ibu hamil anemia di 
Kecamatan Ampana Tete Kabupaten Tojo Una-una Provinsi Sulawesi Tengah menggunakan metode Branch and Bound.

\subsection{Batasan Penelitian}

Adapun batasan masalah yang akan dibahas adalah:

1. Penelitian dibatasi pada kebutuhan gizi ibu hamil penderita anemia per trimester diambil dari Angka Kecukupan Gizi (AKG).

2. Harga bahan makanan berlaku pada bulan november tahun 2016.

3. Bahan makanan yang akan dikombinasi adalah:
a. Makanan pokok berupa beras sebagai sumber energi.
b. Sayur sebagai pengatur: berupa wortel, bayam, dan kangkung.
c. Buah-buahan sebagai pengatur: pisang, pepaya dan jeruk.
d. Lauk pauk sebagai pembangun: ikan, telur ayam, tempe dan tahu.
e. Makanan tambahan seperti: Kacang hijau dan susu.

\section{METODE PENELITIAN}

Prosedur penelitian ini adalah sebagai berikut:

1. Mulai penelitian

2. Studi literature dilakukan dengan mengumpulkan materi dari buku, artikel, dan jurnal

3. Pengambilan data

4. Memformulasikan masalah kedalam bentuk program linear dan menentukkan variabel dari setiap masalah $\left(x_{j}\right)$

5. Menentukkan model matematis

6. Menyelesaikan model matematis menggunakan metode Simpleks dengan aplikasi TORA

7. Solusi integer dengan metode Branch and Bound dengan menentukkan batas serta cabang pada solusi simpleks non integer

8. Penyelesaian Branch and Bound dengan menggunakan aplikasi TORA

9. Mendapatkan solusi yang integer dan optimal

10. Menyimpulkan hasil penelitian

11. Selesai

\section{HASIL DAN PEMBAHASAN}

\subsection{Pengumpulan Data}

Tabel 1 : Daftar Kandungan Zat Gizi per Gram

\begin{tabular}{|c|c|c|c|c|c|c|c|c|c|}
\hline \multirow{2}{*}{ No. } & \multirow{2}{*}{ Bahan } & Energi & Protein & Lemak & karbohidrat & Kalsium & Besi & Vit. A & Vit. C \\
\cline { 3 - 11 } & & $(\mathrm{kkal})$ & $(\mathrm{g})$ & $(\mathrm{g})$ & $(\mathrm{g})$ & $(\mathrm{mg})$ & $(\mathrm{mg})$ & $(\mathrm{mg})$ & $(\mathrm{mg})$ \\
\hline 1. & Beras & 3,600 & 0,068 & 0,007 & 0,789 & 0,060 & 0,008 & 0,000 & 0,000 \\
\hline
\end{tabular}




\begin{tabular}{|c|c|c|c|c|c|c|c|c|c|}
\hline 2. & $\begin{array}{c}\text { Ikan } \\
\text { Segar }\end{array}$ & 0,904 & 0,136 & 0,036 & 0,000 & 0,160 & 0,008 & 0,376 & 0,000 \\
\hline 3. & Telur ayam & 1,620 & 0,128 & 0,115 & 0,007 & 0,540 & 0,027 & 3,090 & 0,000 \\
\hline 4. & Tempe & 1,490 & 0,183 & 0,040 & 0,127 & 1,290 & 0,100 & 0,060 & 0,000 \\
\hline 5. & Tahu & 0,680 & 0,780 & 0,046 & 0,016 & 1,240 & 0,000 & 0,000 & 0,000 \\
\hline 6. & Wortel & 0,370 & 0,011 & 0,003 & 0,082 & 0,343 & 0,007 & 15,840 & 0,053 \\
\hline 7. & Kangkung & 0,203 & 0,021 & 0,002 & 0,038 & 0,511 & 6,615 & 0,018 & 0,224 \\
\hline 8. & Bayam & 0,510 & 0,046 & 0,005 & 0,100 & 3,680 & 8,700 & 0,022 & 0,800 \\
\hline 9. & Pisang & 1,200 & 0,102 & 0,002 & 0,318 & 0,100 & 0,004 & 1,390 & 0,100 \\
\hline 10. & Pepaya & 0,460 & 0,005 & 0,000 & 0,122 & 0,230 & 0,017 & 0,560 & 0,780 \\
\hline 11 & $\begin{array}{c}\text { Jeruk } \\
\text { Manis }\end{array}$ & 0,450 & 0,009 & 0,002 & 0,112 & 0,330 & 0,004 & 0,290 & 0,490 \\
\hline 13. & Kacang & 3,450 & 0,222 & 0,012 & 0,620 & 1,250 & 0,070 & 1,570 & 0,060 \\
\hline
\end{tabular}

Sumber: Badan Ketahanan Pangan Daerah Sulawesi Tengah, tahun 2016

Tabel 2 : Angka Kecukupan Gizi (AKG) harian yang dianjurkan untuk ibu hamil anemia

\begin{tabular}{|l|c|c|c|}
\hline \multirow{2}{*}{ Zat Gizi } & \multicolumn{3}{|c|}{ AKG Wanita Hamil Anemia } \\
\cline { 2 - 4 } & Trimester 1 & Trimester 2 & Trimester 3 \\
\hline Energi (kkal) & 2300 & 2500 & 2500 \\
\hline Protein (gram) & 76 & 76 & 76 \\
\hline Lemak (gram) & 60 & 85 & 110 \\
\hline Karbohidrat (gram) & 375 & 400 & 400 \\
\hline Kalsium (mg) & 800 & 1200 & 1200 \\
\hline Besi (mg) & 28 & 36 & 40 \\
\hline Vitamin A (mg) & 700 & 700 & 700 \\
\hline Vitamin C (mg) & 100 & 100 & 100 \\
\hline
\end{tabular}

Sumber: Puskesmas Tete, Kecamatan Ampana Tete Kabupaten Tojo Una-Una

Tabel 3 : Daftar harga bahan makanan di pasar

\begin{tabular}{|l|l|c|c|}
\hline No. & \multicolumn{1}{|c|}{ Bahan } & Harga (Rp/kg) & Harga (Rp/gr) \\
\hline 1. & Beras & Rp. 10.000 & 10 \\
\hline 2. & Ikan segar & Rp. 25.000 & 25 \\
\hline 3. & Telur Ayam & Rp. 18.000 & 18 \\
\hline 4. & Tempe & Rp. 12.000 & 12 \\
\hline
\end{tabular}




\begin{tabular}{|l|l|c|c|}
\hline 5. & Tahu & Rp. 9.000 & 9 \\
\hline 5. & Wortel & Rp. 13.000 & 13 \\
\hline 6. & Bayam & Rp. 8.000 & 8 \\
\hline 7. & Kangkung & Rp. 8.000 & 8 \\
\hline 8. & Pisang & Rp. 5.000 & 5 \\
\hline 9. & Pepaya & Rp.7.000 & 7 \\
\hline 10. & Jeruk Manis & Rp. 10.000 & 10 \\
\hline 11. & Kacang Hijau & Rp. 18.000 & 18 \\
\hline 12. & Susu & Rp. 53.500 & 53,5 \\
\hline
\end{tabular}

Sumber: Data survei wawancara di pasar Ampana

\subsection{Model Program Linear}

Bahan makanan yang di bentuk adalah sebagai berikut:

a. Makanan pokok berupa beras sebagai sumber energi.

b. Sayur sebagai pengatur: berupa wortel, bayam, dan kangkung.

c. Buah-buahan sebagai pengatur: pisang, pepaya dan jeruk.

d. Lauk pauk sebagai pembangun: ikan, telur ayam, tempe dan tahu.

e. Makanan tambahan seperti kacang hijau dan susu.

\section{Penentuan peubah keputusan}

Dalam menentukan peubah keputusan dinyatakan sebagai berikut:

$x_{1}=$ Jenis makanan pokok yaitu beras dalam kombinasi makanan

$x_{2}=$ Jenis sayur yakni wortel, bayam, dan kangkung dalam kombinasi makanan

$x_{3}=$ Jenis buah yakni pisang, pepaya dan jeruk dalam kombinasi makanan

$x_{4}=$ Jenis lauk pauk yakni ikan, telur ayam, tempe dan tahu dalam kombinasi makanan

$x_{5}=$ Kacang hijau dalam kombinasi makanan

$x_{6}=$ Susu dalam kombinasi makanan

\subsection{Penyelesaian Metode Simpleks Menggunakan Program TORA}

Model matematika yang telah dibuat pada kombinasi makanan, diubah ke dalam bentuk standar untuk masing-masing kasusnya, yakni dengan menambahkan peubah surplus yaitu $S_{j}$ dengan $j=1,2, \ldots 8$ dan peubah artificial yaitu $R_{k}$ dengan $k=1,2, \ldots 8$ pada fungsi kendala sehingga kendala berubah menjadi $\sum_{j}^{n} a_{i j} x_{j}-S_{j}+R_{k}=b_{i}$.

Sebagai ilustrasi, penyelesaian kasus di atas dapat dilihat pada penyelesaian kombinasi pertama pada trimester 1 sebagai berikut:

Fungsi Tujuan:

Minimumkan $Z=10.000 x_{1}+13.000 x_{2}+5.000 x_{3}+25.000 x_{4}+18.000 x_{5}+53.500 x_{6}$ 
Kendala untuk ibu hamil anemia Trimester I:

$3,600 x_{1}+0,370 x_{2}+1,200 x_{3}+0,904 x_{4}+3,450 x_{5}+3,360 x_{6}-S_{1}+R_{1} \geq 2300$

$0,068 x_{1}+0,011 x_{2}+0,102 x_{3}+0,136 x_{4}+0,222 x_{5}+0,082 x_{6}-S_{2}+R_{2} \geq 76$

$0,007 x_{1}+0,003 x_{2}+0,002 x_{3}+0,036 x_{4}+0,012 x_{5}+0,100 x_{6}-S_{3}+R_{3} \geq 60$

$0,789 x_{1}+0,082 x_{2}+0,318 x_{3}+0,620 x_{5}+0,550 x_{6}-S_{4}+R_{4} \geq 375$

$0,060 x_{1}+0,343 x_{2}+0,100 x_{3}+0,160 x_{4}+1,250 x_{5}+2,750 x_{6}-S_{5}+R_{5} \geq 800$

$0,008 x_{1}+0,007 x_{2}+0,004 x_{3}+0,008 x_{4}+0,070 x_{5}+0,066 x_{6}-S_{6}+R_{6} \geq 28$

$15,840 x_{2}+1,390 x_{3}+0,376 x_{4}+1,470 x_{5}+1,750 x_{6}-S_{7}+R_{7} \geq 700$

$0,053 x_{2}+0,100 x_{3}+0,060 x_{5}+0,010 x_{6}-S_{8}+R_{8} \geq 100$

\subsection{Solusi Integer dengan Metode Branch and Bound}

Persoalan Program Integer (IP) adalah persoalan pemograman (programming) dimana pemecahan optimalnya harus menghasilkan bilangan integer ( bulat) jadi bukan pecahan. Dengan perkataan lain dari antara berbagai bilangan integer, harus dicari nilai-nilai variabel yang fisibel (layak) dan membuat fungsi tujuan (objective function) minimum (Supranto, 1980).

Menurut Meicicho (2013) Metode Branch and Bound merupakan salah satu metode untuk menghasilkan penyelesaian optimal pemrograman linear yang menghasilkan variabelvariabel keputusan bilangan bulat. Branch and Bound secara sistematis mengabaikan sekumpulan kandidat solusi tidak potensial menuju solusi optimal dengan menggunakan estimasi batas atas dan batas bawah (upper and lower estimated bounds) dari kualitas yang dioptimalkan (Rifaldi, 2015).

\subsubsection{Menentukkan Batas atas dan Batas Bawah (Branch)}

a. Trimester I: Solusi optimal dari penyelesaian metode simpleks didapatkan $x_{1}=$ $347,51, x_{2}=114,60, x_{3}=0, x_{4}=481,13, x_{5}=138,69$, dan $x_{6}=0$ dijadikan batas bawah awal yaitu: $z=15548,65$. Sedangkan hasil pembulatan ke atas sebagai batas atas $x_{1}=348, x_{2}=115, x_{3}=0, x_{4}=481, x_{5}=139$, dan $x_{6}=0$, berdasarkan fungsi tujuan maka di dapatkan batas bawah yaitu: $z=15560,00$.

b. Trimester 2: Solusi optimal dari penyelesaian metode simpleks didapatkan $x_{1}=$ $359,31, x_{2}=166,33, x_{3}=0, x_{4}=694,04, x_{5}=153,25$, dan $x_{6}=0$ dijadikan batas bawah awal yaitu: $z=20174,85$. Sedangkan hasil pembulatan ke atas sebagai batas atas $x_{1}=359, x_{2}=166, x_{3}=0, x_{4}=694, x_{5}=153$, dan $x_{6}=0$, berdasarkan fungsi tujuan maka di dapatkan batas atas yaitu: $z=20164,00$.

c. Trimester 3: Solusi optimal dari penyelesaian metode simpleks didapatkan $x_{1}=$ $377,66, x_{2}=141,20, x_{3}=0, x_{4}=913,68, x_{5}=131,47$, dan $x_{6}=0$ dijadikan batas atas awal yaitu: $z=23718,84$. Sedangkan hasil pembulatan ke atas sebagai batas atas $x_{1}=378, x_{2}=141, x_{3}=0, x_{4}=914, x_{5}=131$, dan $x_{6}=0$, berdasarkan fungsi tujuan maka di dapatkan batas atas yaitu: $z=23683,00$. 


\subsubsection{Pencabangan (Bound)}

a. Trimester I: Karena $x_{5}=138,69$ memiliki nilai pecah terbesar, dua kendala baru di ciptakan sehingga diperoleh dua masalah baru melalui dua kendala mutually exclusive sebagai berikut: $x_{5} \leq 138$ dan $x_{5} \geq 139$.

b. Trimester 2: Karena $x_{2}=166,33$ memiliki nilai pecah terbesar, dua kendala baru di ciptakan sehingga diperoleh dua masalah baru melalui dua kendala mutually exclusive sebagai berikut: $x_{2} \leq 166$ dan $x_{2} \geq 167$.

c. Trimester 3: Karena $x_{4}=913,68$ memiliki nilai pecah terbesar, dua kendala baru di ciptakan sehingga diperoleh dua masalah baru melalui dua kendala mutually exclusive sebagai berikut: $x_{4} \leq 913$ dan $x_{4} \geq 914$.

Masukkan masing-masing nilai kendala baru dari hasil pencabangan pada nilai kendala dan fungsi tujuan asli, pada solusi cabang yang tidak layak bisa dibuang atau dihentikkan.

Proses pencabangan dilakukan terus berdasarkan kendala yang didapatkan untuk masing-masing trimester hingga mendapatkan solusi bulat layak. Pada trimester didapatkan solusi bulat layak dimana Batas atas $=$ Batas bawah $=z=$ 15683,00, Trimester 2 didapatkan solusi bulat layak dimana Batas atas $=$ Batas bawah $=z=20498,50$, trimester 3 didapatkan solusi bulat layak Batas atas = Batas bawah $=z=24086,00$. Dapat dilihat pada prosedur Branch and Bound di bawah ini: 


\subsubsection{Prosedur Branch and bound}

Trimester 1

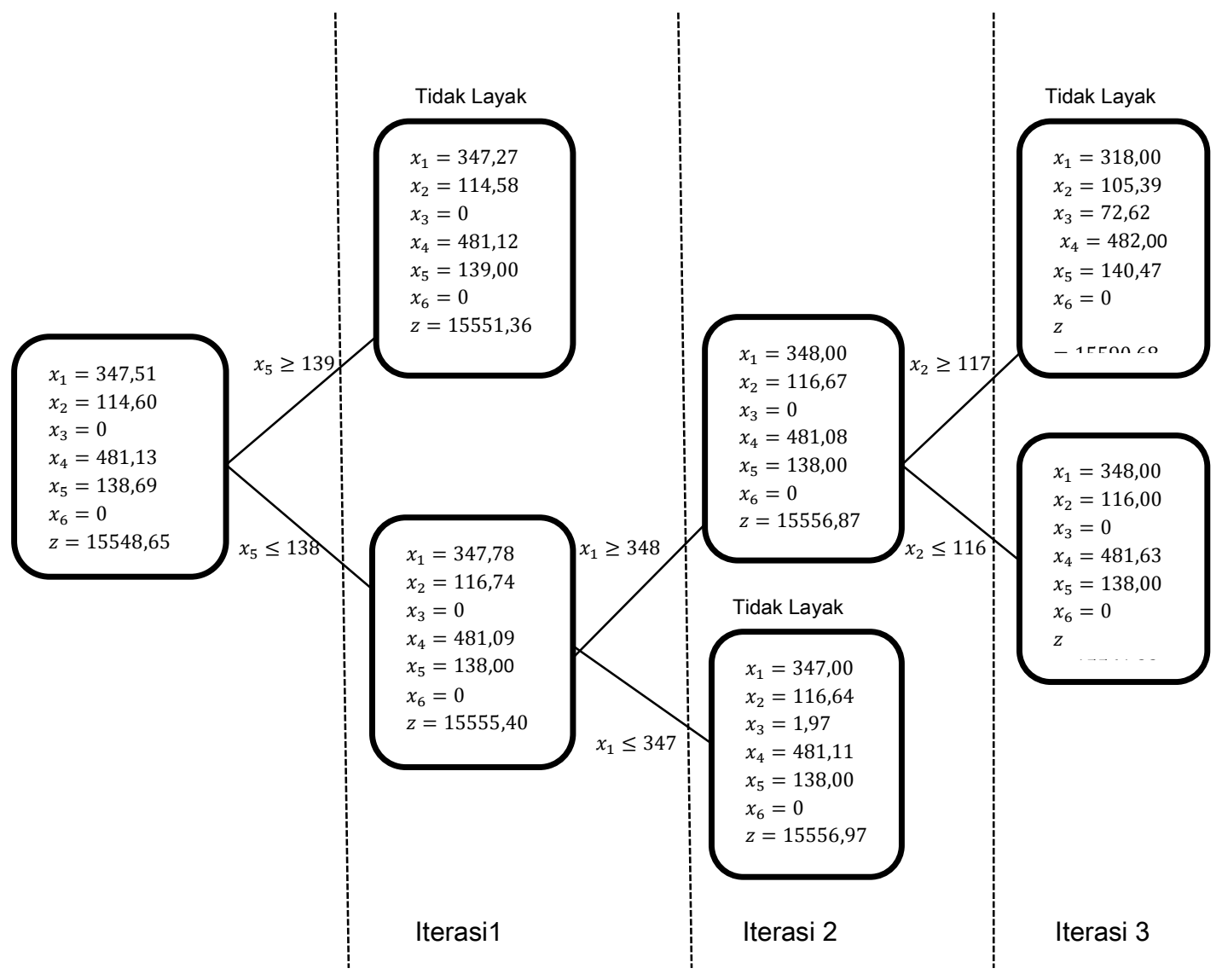




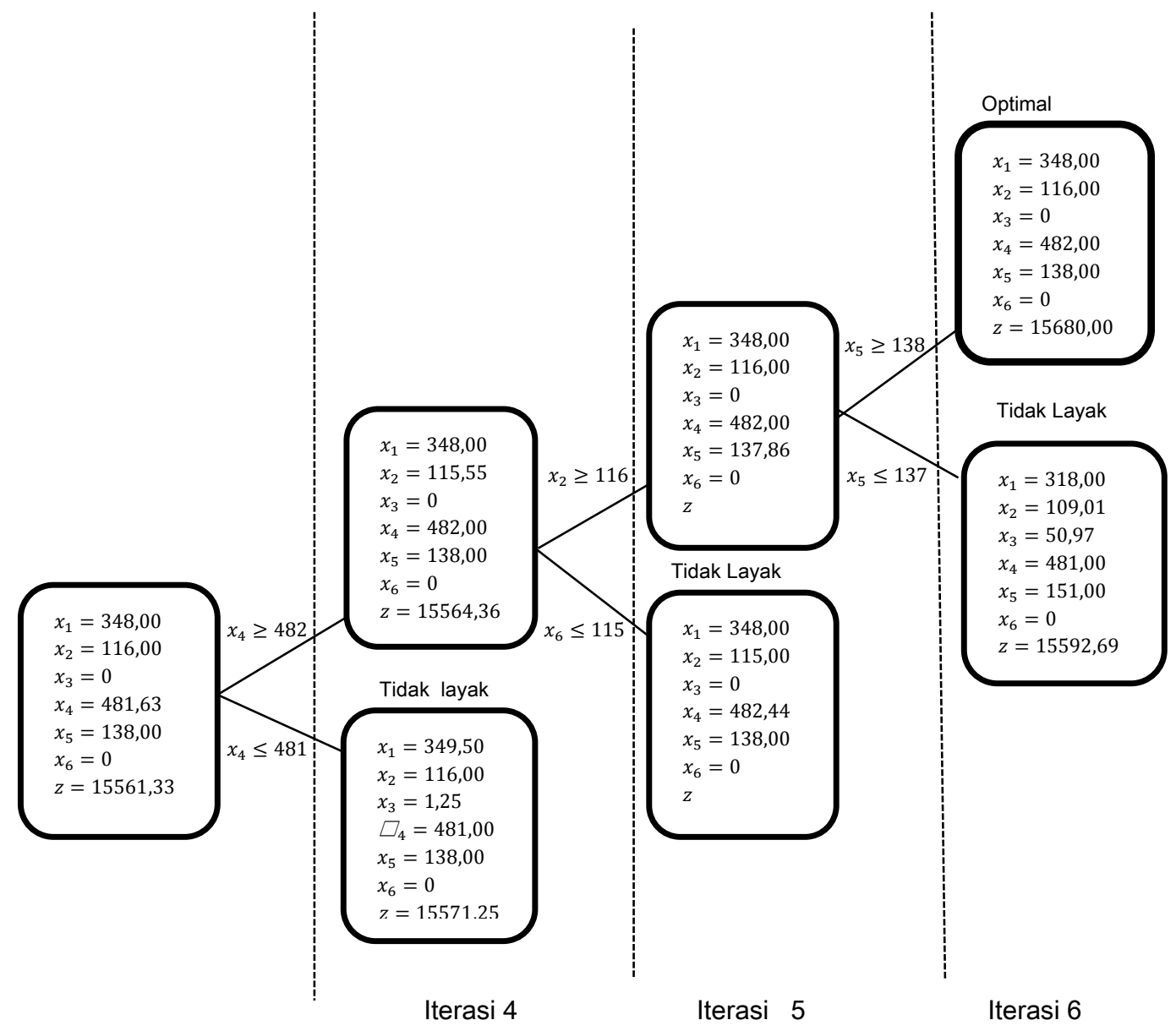

Gambar 1 : Prosedur Branch and Bound

Selanjutnya prosedur branch and bound untuk trimester 2 dan 3 dikerjakan sampai mendapatkan hasil yang optimal seperti pada trimester 1 .

\subsection{Pembahasan}

Optimalisasi dilakukan untuk mendapatkan hasil kebutuhan gizi pada menu makanan ibu hamil anemia dengan biaya yang minimum, dengan harga bahan makanan yang tidak berfluktuasi. Berdasarkan hasil penyelesaian pada bagian 4.1.3 ,dengan menggunakan metode Branch And Bound didapatkan penyelesaian optimal bulatnya adalah:

a. Trimester 1 dengan $x_{1}$ yaitu beras sebanyak $318 \mathrm{~g}, x_{2}$ yaitu bayam sebanyak $116 \mathrm{~g}, x_{4}$ yaitu telur ayam sebanyak $482 \mathrm{~g}$, dan $x_{5}$ yaitu kacang hijau sebanyak $138 \mathrm{~g}$, dengan 
harga Rp15.680,00. Kandungan gizi yang terdapat dalam bahan makanan tersebut yaitu energi 2568,9 kkal, protein $84,092 \mathrm{~g}$, lemak $60 \mathrm{~g}$, karbohidrat $375 \mathrm{~g}$, kalsium $880,54 \mathrm{mg}$, zat besi $28 \mathrm{mg}$, vitamin A 766,964 mg, dan vitamin C 101,08 mg.

b. $\quad$ Trimester 2 dengan $x_{1}$ yaitu beras sebanyak $381 \mathrm{~g}, x_{2}$ yaitu bayam sebanyak $167 \mathrm{~g}, x_{4}$ yaitu telur ayam sebanyak $690 \mathrm{~g}, x_{5}$ yaitu kacang hijau sebanyak $154 \mathrm{~g}$, dan $x_{6}$ yaitu susu sebanyak $3 \mathrm{~g}$, dengan harga Rp 20.489,50. Kandungan gizi yang terdapat dalam bahan makanan tersebut yaitu energi $3115,95 \mathrm{kkal}$, protein 101,39 g, lemak $85 \mathrm{~g}$, karbohidrat 419,26 g, kalsium 1247,27 mg, zat besi $36 \mathrm{mg}$, vitamin A 1042,85 mg, dan vitamin C $142,87 \mathrm{mg}$.

c. Trimester 3 dengan $x_{1}$ yaitu beras sebanyak $345 \mathrm{~g}, x_{2}$ yaitu bayam sebanyak $127 \mathrm{~g}, x_{4}$ yaitu telur ayam sebanyak $914 \mathrm{~g}$, dan $x_{5}$ yaitu kacang hijau sebanyak $176 \mathrm{~g}$, dengan harga $\mathrm{Rp} 24.086,00$. Kandungan gizi yang terdapat dalam bahan makanan tersebut yaitu energi 3394,65 kkal, protein $114 \mathrm{~g}$, lemak $110 \mathrm{~g}$, karbohidrat $400 \mathrm{~g}$, kalsium 1201,62 mg, zat besi 42,54 mg, vitamin A 911,08 mg, dan vitamin C 112,16 mg.

Menurut (Hardinsyah, 2012) batas atas yang diperbolehkan yaitu 50\% dari AKG yang dianjurkan. Batas atas adalah nilai rata-rata tertinggi asupan gizi harian yang tidak menimbulkan resiko gangguan kesehatan lainnya. Bila asupan lebih besar dari batas atas maka potensi mengalami gangguan kesehatan mungkin meningkat. Jadi kelebihan zat gizi lainnya tidak berdampak yang signifikan untuk ibu hamil anemia trimester 1, 2, dan 3 .

\section{KESIMPULAN}

Berdasarkan penelitian pada bab-bab sebelumnya, maka dapat disimpulkan bahwa:

1. Solusi integer kebutuhan gizi pada menu makanan ibu hamil anemia Trimester 1 menggunakan metode Branch and Bound menghasilkan $x_{1}$ yaitu beras sebanyak $348 \mathrm{~g}$ , $x_{2}$ yaitu bayam sebanyak $116 \mathrm{~g}, x_{4}$ yaitu telur ayam sebanyak $482 \mathrm{~g}$ dan $x_{5}$ kacang hijau sebanyak $138 \mathrm{~g}$ dengan Rp 15.568,00. Trimester 2 adalah $x_{1}$ beras sebanyak 318 $\mathrm{g}, x_{2}$ yaitu bayam sebanyak $167 \mathrm{~g}, x_{4}$ yaitu telur ayam sebanyak $690 \mathrm{~g}, x_{5}$ yaitu kacang hijau sebanyak $154 \mathrm{~g}$, dan $x_{6}$ yaitu susu sebanyak $3 \mathrm{~g}$ dengan $\mathrm{Rp} 20.498,50$. dan Trimester 3 adalah $x_{1}$ beras sebanyak $345 \mathrm{~g}, x_{2}$ yaitu bayam sebanyak $127 \mathrm{~g}, x_{4}$ yaitu telur ayam sebanyak $914 \mathrm{~g}$, dan $x_{5}$ yaitu kacang hijau sebanyak $176 \mathrm{~g}$ dengan Rp 24.086,00. 


\section{DAFTAR PUSTAKA}

[1] Badan Ketahanan Pangan Daerah Sulawesi Tengah (2016).

[2] Hamdy, A Taha. (1996). Riset Operasi, Lembaga Penerbit Bina Putra Aksara, Jakarta.

[3] Hardinsyah. (2012). Kecukupan Energi, Lemak, Protein dan Karbohidrat. Skripsi. Bogor: IPB

[4] Meicicho, M (2013). Optimalisasi Kebutuhan Gizi Pada Menu Makanan Diabetes Melitus dengan Metode Branch and Bound (Studi Kasus Rumah Sakit M. Yunus, Bengkulu), Fakultas MIPA Universitas Brawijaya, Malang.

[5] Puskesmas Tete, Kecamatan Ampana Tete Kabupaten Tojo Una-Una Provinsi Sulawesi Tengah. (2016).

[6] Rifaldi, K. (2015). Optimalisasi Hasil Produksi Tahu dan Tempe Menggunakan Metode Branch and Bound (Studi Kasus Pabrik Tempe ERI jln. Teratai No.04 Palu Selatan), Fakultas MIPA Universitas Tadulako, Palu.

[7] Supranto, J. (1980). Linear Programming. Fakultas Ekonomi Universitas Indonesia Jakarta.

[8] Tarwoto dan Wasnidar. (2007). Buku Saku anemia pada Ibu Hamil dan Konsep penatalaksanaan. Jakarta:Trans Info Media. 